\title{
Prokaryotic Expression and Confirmation of Non-structural Protein C of Peste-Des-Petits-Ruminants Virus
}

\author{
S. Bhadouriya ${ }^{1}$, D. Choudhary ${ }^{1}$, A. Yadav', S. Chandra Sekar ${ }^{1}$, V.V. Dhanesh ${ }^{1}$, \\ M. Sankar ${ }^{1}$, K.K. Rajak ${ }^{2}$, R.P. Singh ${ }^{2}$, M.A. Ramakrishnan ${ }^{1}$, \\ A.B. Pandey ${ }^{2}$ and D. Muthuchelvan ${ }^{1 *}$ \\ ${ }^{1}$ Division of Virology, ICAR-Indian Veterinary Research Institute, Mukteswar, Nainital \\ District, Uttarakhand 263 138, India
}

*Corresponding author

A B S T R A C T

\section{Keywords \\ Peste-des-petits- ruminants, PPR, PPRV, Non- structural protein $\mathrm{C}$, Prokaryotic expression \\ Article Info \\ Accepted: \\ 17 January 2018 Available Online: 10 February 2018}

Peste-des-petits-ruminants (PPR) is a transboundary viral disease of small ruminants. In the present study, the full length $\mathrm{C}$ gene was amplified from PPR vaccine virus (Sungri/96) and expressed in a prokaryotic expression system. Specificity of the recombinant $\mathrm{C}$ protein was confirmed through immune-blot using anti-His conjugate and hyperimmune sera from goats. The immunogenicity of the protein was assessed using monospecific sera raised in goats. The recombinant $\mathrm{C}$ protein produced in this study will be useful for the development of DIVA enabled vaccine and diagnostics.

\section{Introduction}

Peste-des-petits -ruminants (PPR) is a devastating viral disease of small ruminants. Presence of this disease hampers the livelihood of poor farmers and is targeted for global eradication in 2030 by FAO and OIE (Muthuchelvan et al., 2015; Parida et al., 2015). The morbidity and mortality rates may vary depending on the virulence of the outbreak strain, breed, age, sex and the immune status of the host. The case fatality rate can go up to $100 \%$ in naïve population (Lefevre and Diallo, 1990). Generally, goats exhibit more severe clinical symptoms than sheep (Sen et al., 2010). The etiological agent, small ruminant morbillivirus peste-despetits-ruminants virus (PPRV) belongs to the genus Morbillivirus of the family Paramyxoviridae. Although the PPRV is single serotype, genetically it can be classified into four distinct lineages (I, II, III, and IV) based on F gene (Shaila et al., 1996) and $\mathrm{N}$ gene (Kwiatek et al., 2007). Occurrences of 
all four lineages have been reported in many countries of Africa whereas only lineage IV has been reported across Asia (Banyard et al., 2010; Muthuchelvan et al., 2015; Parida et al., 2015).The virus codes for six structural (N, P, M, F, H \& L) and two non-structural proteins (C \& V) (Bailey et al., 2005).

PPR is enzootic in India and the outbreaks are being regularly reported (Muthuchelvan et al., 2015). Live attenuated PPR vaccine and MAb based competitive and sandwich ELISAs has been developed by IVRI. Availability of these indigenous technologies helped the Govt. of India to launch a national control programin 2010 which resulted in significant reduction of PPR outbreaks in some states. However, the protective herd immunity has yet to be established for the whole country (Muthuchelvan et al., 2014). The present vaccine being a live attenuated vaccine is expected to induce antibodies against all the viral proteins. Therefore, differentiating the infected from the vaccinated animals (DIVA) is difficult. Developing DIVA enabled vaccine and the diagnostic assay is need of the hour.

The PPRV codes for two non-structural proteins $(\mathrm{C} \& \mathrm{~V})$ from the $\mathrm{P}$ ORF. The $\mathrm{C}$ protein is generated from the alternate start codon of the P ORF (Bailey et al., 2005; Muthuchelvan et al., 2006). It is a small basic nonphosphorylated protein with a molecular weight of 19-21 kDa. Two primary functions of $\mathrm{C}$ protein of paramyxoviridae have been reported, prevention of host innate immunity and control of viral RNA synthesis (Garcin et al., 1999). Itaugments the maturation of infectious particle, has an antagonistic action against IFN and modulates RNA polymerase activity (Horvath, 2004). This protein can occur in both nucleus and cytoplasm of infected cells in Measles Virus and only in the cytoplasm of Rinder pest virus (Patterson et $a l ., 2000)$ and blocks the type I interferon in rinderpest virus (Boxer et al., 2009). In the present study, we expressed the $\mathrm{C}$ protein of PPRV in prokaryotic expression system and confirmed it through immune-blot using antiHis and hyperimmune sera raised in goats. The reactivity of the recombinant protein was assessed using monospecific sera raised in rabbits.

The PPR vaccine virus (Sungri 96 isolate) was propagated as per standard protocol and the viral RNA and cDNA was prepared as described earlier (Muthuchelvan et al., 2014). The PPRV $\mathrm{C}$ gene-specific primers [C-F (NcoI): CCG CCA TGG GGA TGT CAA CAA GGG GCT GGA ATG and C-R (Hind III): GCG AAG CTT GTT TCT CGA CAT CTG TGG ACC TAG] were designed using published sequence (GenBank Accession \# AY560591). The amplification was carried out using $P f u$ DNA polymerase (M/s MBI, Thermoscientific, Maryland, USA) and the cycling conditions followed were: preheating at $95{ }^{\circ} \mathrm{C}$ for $5 \mathrm{~min}, 35$ cycles of $95^{\circ} \mathrm{C}$ for 30 sec, $64{ }^{\circ} \mathrm{C}$ for $30 \mathrm{sec}$ and $72{ }^{\circ} \mathrm{C}$ for $1 \mathrm{~min}$ with a final extension of $72{ }^{\circ} \mathrm{C}$ for $10 \mathrm{~min}$. The PCR amplicons were gel purified and cloned directionally into pET32a vector (Novagen, Madison, WI, USA) at the NcoI and Hind III restriction sites. The recombinant clones were selected on LB agar plates containing ampicillin $(50 \mu \mathrm{g} / \mathrm{ml})$ and were verified by colony PCR, restriction enzyme analysis,and sequencing.

E. coli BL21 cells were transformed with recombinant plasmids and grown at $37{ }^{\circ} \mathrm{C}$ overnight, on LB agar plates containing chloramphenicol $(34 \mu \mathrm{g} / \mathrm{ml})$ and amplicillin (50 $\mu \mathrm{g} / \mathrm{ml}$ ). The positive colonies were screened by colony PCR and grown at $37{ }^{\circ} \mathrm{C}$ till the culture reached mid-log phase $\left(\mathrm{OD}_{600}\right.$ $\mathrm{nm}$ of $0.4-0.5)$. The protein expression was induced at $30{ }^{\circ} \mathrm{C}$ by using $1 \mathrm{mM}$ IPTG. Samples were collected at 2, 4 and 6 h postinduction (hpi) and were analyzed by SDS- 
PAGE and immune-blot as per standard procedures.

Five hundred microlitres of induced bacterial culture were harvested at $4 \mathrm{hpi}$, centrifuged at $6000 \times g$ for $10 \mathrm{~min}$ and the cell pellet was suspended in denaturing buffer (Invitrogen Corporation, Carlsbad, CA). The denatured pellet was centrifuged at $10,000 \times g$ for 10 min at $4{ }^{\circ} \mathrm{C}$ and the supernatant was collected and purified using nickel affinity columns according to the manufacturer's instructions (M/s Qiagen, Hilden, Germany). The final concentration of purified protein was estimated calorimetrically using Micro BCA Protein Assay Kit (Pierce, Rockford, IL, USA), as well as using Nanovue spectrophotometer (General Electric, USA).

The harvested post-induced samples, mock vector transformed bacteria, host bacteria and eluted fractions were mixed separately with SDS sample buffer and resolved by polyacrylamide gel (5\% stacking and 12\% resolving). The resolved proteins were transferred on to a nitrocellulose membrane (M/s Pharmacia Biotech, USA using semi-dry blot system (M/s ATTO corporation, Japan). The recombinant proteins on the blot were detected by incubation with Ni-NTA HRP conjugate in goats or hyperimmune sera raised in goats as per the standard procedure.

The immunogenicity of the recombinant $\mathrm{C}$ protein was assessed in terms of immune response in rabbits. The purified protein (150 $\mu \mathrm{g})$ was mixed with equal volume of Freund's complete or incomplete adjuvant for primary or booster immunization respectively. The booster immunization was carried outon 21 and 28 days withFreund's incomplete adjuvant (FIA) in the same way and injected intradermally. All the animals were bled at 0 , $21^{\text {st }}, 28^{\text {th }}$ and $42^{\text {nd }}$-day post inoculation. The serum was harvested from blood and complement inactivation was done by keeping at $56^{\circ} \mathrm{C}$ for $30 \mathrm{~min}$ and then used to check the reactivity in an indirect ELISA.

The PPRV lineage four is now being reported in several countries in Africa, Europe, and Asia (Banyard et al., 2010; Parida et al., 2015). Global control and eradication efforts are currently underway (Parida et al., 2015) which means there is a need to develop modern vaccines and diagnostics that can differentiate the vaccinated from the infected animals (DIVA). At present, two groups have successfully rescued the PPR vaccine virus (Hu et al., 2012; Muniraju et al., 2015). However, currently, there is no marker vaccine and diagnostic test available in the market. Developing marker vaccine by altering the non-structural proteins can be an attractive option. To adopt this strategy, we need to have either a monoclonal antibody or monospecific antisera against the nonstructural proteins. In the present study, we have expressed the non-structural $\mathrm{C}$ protein in the prokaryotic system and evaluated the immunogenicity of the recombinant protein through monospecific sera raised in rabbits.

The full-length recombinant $\mathrm{C}$ protein was expressed in E. coli and confirmed in SDSPAGE and in immune-blot. The calculated molecular weight of the protein is $19 \mathrm{kDa}$ and the His-tagged protein was expected to have a size of $39 \mathrm{kDa}$ which is in agreement with the observed result in SDS-PAGE (Fig. 1A) and in immune-blot with anti His conjugate (Fig. 1B) and with hyperimmune sera of goat (Fig. 1C). The yield of the protein was estimated to be $2.9 \mathrm{mg} / \mathrm{mL}$ in adenatured condition which is better than the yield reported for $\mathrm{N}$ protein (Yadav et al., 2009). The monospecific sera raised in rabbits were evaluated for reactivity in an indirect ELISA. The optimum concentration of recombinant antigen and hyperimmune sear for use in indirect ELISA were $1 \mu \mathrm{g}$ per well of antigenand 1: 160 of hyperimmune sera (Fig. 
2). The recombinant protein produced in the study has good yield in denatured condition and the monospecific sera could be produced in rabbits indicate that some of the linear epitopes present in the protein is immunogenic and could be targeted for development of marker vaccines. Studying the reactivity of this protein with vaccinated and convalescent sera may shed more light on the nature of this protein and its role during virus multiplication and disease spread.

Fig.1 Characterization of the recombinant PPRV C protein: (A) SDS-PAGE analysis of BL21 codon plus post induction culture lysate: Lane M-Prestained protein marker (M/s MBI,

Fermentas; Lanes 1-5: 0h; 6h;4h;2h;uninduced culture lysate. (B) Western blotanalysis of BL21 codon plus post induction culture lysate reactivity with anti His conjugate: Lane M-Prestained protein marker (M/s MBI, Fermentas; Lanes 1-5: 0h; 6h;4h;2h;uninduced culture lysate. C): Western blotanalysis of purified recombinant $\mathrm{C}$ protein with hyperimmune sera against whole virus raised in goats

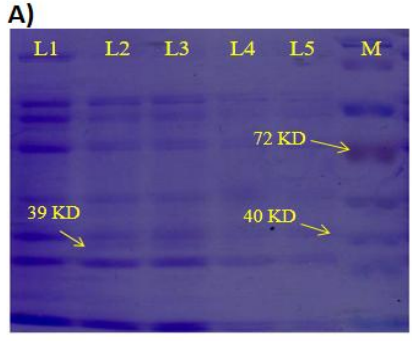

B)
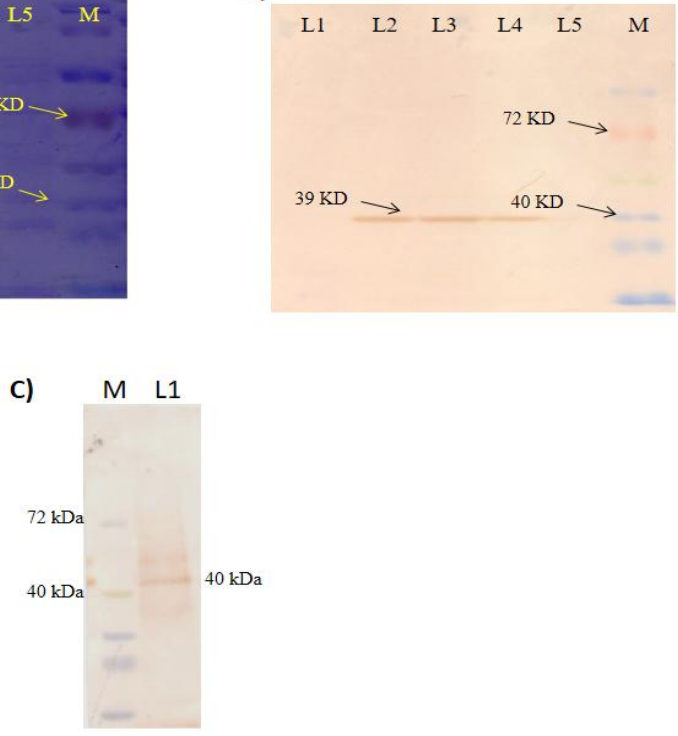

Fig.2 Reactivity of different concentration of recombinant PPRV C protein with hyperimmune sera raised in two rabbits. The negative cut off is $0.24 \mathrm{OD}$ (twice the OD value of reactivity of two negative sera with recombinant protein)

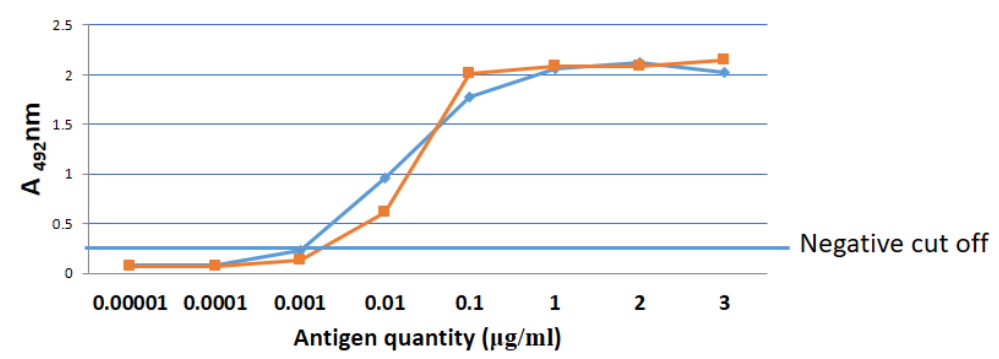


In conclusion, the present study has successfully produced a recombinant form of $\mathrm{C}$ protein and monospecific sera which may be useful in developing DIVA enabled vaccine and diagnostics. Evaluating the reactivity of this protein with convalescent and vaccinated sera may shed more light on the nature of this protein and its biology in the host.

\section{Acknowledgements}

The authors would like to acknowledge funding from DBT-BBSRCBT/IN/IndoUK/FADH/50/GDR/2013 and ICAR-CRP sub-project 8 AS/2/7/2014-ASR-IV. BS acknowledges IVRI for financial support in terms of JRF to carry out the Master's degree Programme.

\section{Conflict of Interest}

The authors declare no conflict of interest.

\section{References}

Bailey, D., Banyard, A., Dash, P., Ozkul, A., Barrett, T., 2005. Full genome sequence of peste des petits ruminants virus, a member of the Morbillivirus genus. Virus Res. 110, 119-124. https://doi. org/10.1016/j.virusres.2005.01.013

Banyard, A.C., Parida, S., Batten, C., Oura, C., Kwiatek, O., Libeau, G., 2010. Global distribution of peste des petits ruminants virus and prospects for improved diagnosis and control. J. Gen. Virol. 91, 2885-2897. https://doi.org/ 10.1099/vir.0.025841-0

Boxer, E.L., Nanda, S.K., Baron, M.D., 2009. The rinderpest virus non-structural $\mathrm{C}$ protein blocks the induction of type 1 interferon. Virology 385, 134-142. https://doi.org/10.1016/j.virol.2008.11.0 22

Garcin, D., Latorre, P., Kolakofsky, D., 1999.
Sendai virus $\mathrm{C}$ proteins counteract the interferon-mediated induction of an antiviral state. J. Virol. 73, 6559-6565.

Horvath, C.M., 2004. Silencing STATs: lessons from paramyxovirus interferon evasion. Cytokine Growth Factor Rev. 15, 117-127. https://doi.org/10.1016/j. cytogfr.2004.02.003

Hu, Q., Chen, W., Huang, K., Baron, M.D., $\mathrm{Bu}, \mathrm{Z}$., 2012. Rescue of recombinant peste des petits ruminants virus: creation of a. Vet. Res. 43, 48. https://doi.org/10.1186/1297-9716-4348

Kwiatek, O., Minet, C., Grillet, C., Hurard, C., Carlsson, E., Karimov, B., Albina, E., Diallo, A., Libeau, G., 2007. Peste des petits ruminants (PPR) outbreak in Tajikistan. J. Comp. Pathol. 136, 111119. https://doi.org/10.1016/j.jcpa.2006. 12.002

Lefevre, P.C., Diallo, A., 1990. Peste des petits ruminants. Rev. Sci. Tech. Int. Off. Epizoot. 9, 935-981.

Muniraju, M., Mahapatra, M., Buczkowski, H., Batten, C., Banyard, A.C., Parida, S., 2015. Rescue of a vaccine strain of peste des petits ruminants virus: In vivo evaluation and comparison with standard vaccine. Vaccine 33, 465-471. https://doi.org/10.1016/j.vaccine.2014.1 0.050

Muthuchelvan, D., De, A., Debnath, B., Choudhary, D., Venkatesan, G., Rajak, K.K., Sudhakar, S.B., Himadri, D., Pandey, A.B., Parida, S., 2014. Molecular characterization of peste-despetits ruminants virus (PPRV) isolated from an outbreak in the IndoBangladesh border of Tripura state of North-East India. Vet. Microbiol. 174, 591-595. https://doi.org/10.1016/j. vetmic .2014.10.027

Muthuchelvan, D., Rajak, K.K., Ramakrishnan, M.A., Choudhary, D., Bhadouriya, S., Saravanan, P., Pandey, 
A.B., Singh, R.K., 2015. Peste-despetits-ruminants: An Indian perspective. Adv Anim Vet Sci 3, 422-429.

Muthuchelvan, D., Sanyal, A., Sarkar, J., Sreenivasa, B.P., Bandyopadhyay, S.K., 2006. Comparative nucleotide sequence analysis of the phosphoprotein gene of pestedes petits ruminants vaccine virus of Indian origin. Res. Vet. Sci. 81, 158164. https://doi.org/10.1016/j.rvsc. 2005.09.001

Parida, S., Muniraju, M., Mahapatra, M., Muthuchelvan, D., Buczkowski, H., Banyard, A.C., 2015. Peste des petits ruminants. Vet. Microbiol. 181, 90-106. https://doi.org/10.1016/j.vetmic.2015.08 .009

Patterson, J.B., Thomas, D., Lewicki, H., Billeter, M.A., Oldstone, M.B., 2000. V and $\mathrm{C}$ proteins of measles virus function as virulence factors in vivo. Virology 267, 80-89. https://doi.org/10.1006/ viro.1999.0118
Sen, A., Saravanan, P., Balamurugan, V., Rajak, K.K., Sudhakar, S.B., Bhanuprakash, V., Parida, S., Singh, R.K., 2010. Vaccines against peste des petits ruminants virus. Expert Rev. Vaccines 9, 785-796. https://doi.org/ 10.1586/erv.10.74

Shaila, M.S., Shamaki, D., Forsyth, M.A., Diallo, A., Goatley, L., Kitching, R.P., Barrett, T., 1996. Geographic distribution and epidemiology of peste des petits ruminants virus. Virus Res. 43, 149-153.

Yadav, V., Balamurugan, V., Bhanuprakash, V., Sen, A., Bhanot, V., Venkatesan, G., Riyesh, T., Singh, R.K., 2009. Expression of Peste des petits ruminants virus nucleocapsid protein in prokaryotic system and its potential use as a diagnostic antigen or immunogen. J. Virol. Methods 162, 56-63. https://doi.org/10.1016/j.jviromet.2009. 07.014 .

\section{How to cite this article:}

Bhadouriya, S., D. Choudhary, A. Yadav, S. Chandra Sekar, V.V. Dhanesh, M. Sankar, K.K. Rajak, R.P. Singh, M.A. Ramakrishnan, A.B. Pandey and Muthuchelvan, D. 2018. Prokaryotic Expression and Confirmation of Non-structural Protein $\mathrm{C}$ of Peste-Des-Petits-Ruminants Virus. Int.J.Curr.Microbiol.App.Sci. 7(02): 2119-2124. doi: https://doi.org/10.20546/ijcmas.2018.702.253 